\title{
Sertifikasi Halal Produk Makanan Sebagai Perlindungan Konsumen Muslim; Studi di Lembaga Pengkajian Pangan Obat-Obatan dan Kosmetika-Majelis Ulama Indonesia Sulawesi Tenggara
}

\author{
Sodiman \\ Institut Agama Islam Negeri Kendari \\ E-Mail: sodimanthegreat@yahoo.co.id
}

\begin{abstract}
The study of halal food has grown rapidly, not only in countries that are predominantly Muslim, but also in Muslim minority countries. The purpose of this article is to reveal how religious norms regarding halal and thoyy food have proceeded into the technoscientific certification of halal certification in Indonesia which is predominantly Muslim through microscopic studies at the Institute for the Study of Food Medicine and Cosmetics-Indonesian Ulama Council (LPPOM-MUI) Southeast Sulawesi.

The study used a qualitative approach with primary data sourced from the institutions and actors involved in the certification process at LPPOM-MUI Southeast Sulawesi, namely directors, employees, auditors and the Southeast Sulawesi MUI Fatwa Council, business actors and consumers of certified food products. Data collection through in-depth interviews, observation, and document studies. Data processing used data reduction techniques, data classification, data display, data interpretation and conclusions.

This study found, first, halal techno-scientifications were run by LPPOM-MUI through standardization (1) of materials, (2) products, (3) production facilities, (4) written procedures for critical activities, and (5) search capabilities. Second, the role of LPPOM-MUI in protecting Muslim consumers as institutions and actors guarding halal standards for products that will circulate to the public. The researcher argues that the impact of halal certification is the protection of consumers (Muslims). However, no illicit (haram) certification is applied to products that are not halal certified to be a gap and space for the circulation of food products, medicines and cosmetics that are not halal to the market (society).
\end{abstract}

Key Words: Halal certification, LPPOM-MUI, halal food, and ulama.

\begin{abstract}
Abstrak
Kajian tentang makanan halal telah berkembang pesat, bukan hanya di negaranegara yang mayoritas penduduknya muslim, tetapi juga di negara-negara minoritas muslim. Tujuan artikel ini adalah mengungkap bagaimana norma agama tentang makanan yang halal dan thoyyibah berproses ke dalam techno-saintifikasi sertifikasi halal di Indonesia yang mayoritas penduduknya muslim melalui kajian secara mikroskopik di Lembaga Pengkajian Pangan Obat-obatan dan Kosmetik-Majelis Ulama Indonesia (LPPOM-MUI) Sulawesi Tenggara.

Penelitian menggunakan pendekatan kualitatif dengan data primer bersumber dari lembaga dan aktor yang terlibat dalam proses sertifikasi di LPPOM-MUI Sulawesi Tenggara yakni direktur, pegawai, auditor dan Dewan Fatwa MUI Sulawesi
\end{abstract}


Tenggara, pelaku usaha dan konsumen produk makanan yang disertifikasi. Pengumpulan data melalui wawancara mendalam, observasi, dan studi dokumen. Pengolahan data digunakan teknik reduksi data, klasifikasi data, display data, interpretasi data dan kongklusi.

Penelitian ini menemukan, pertama techno-saintifikasi halal dijalankan oleh LPPOM-MUI melalui standarisasi (1) bahan, (2) produk, (3) fasilitas produksi, (4) prosedur tertulis untuk aktivitas kritis, dan (5) kemampuan telusur. Kedua, peran LPPOM-MUI dalam perlindungan konsumen muslim sebagai lembaga dan aktor penjaga standar halal terhadap produkyang akan beredar kepada masyarakat. Peneliti berargumen bahwa impact sertifikasi halal adalah terlindunginya konsumen (muslim). Namun, tidak diterapkan sertifikasi haram terhadap produk yang tidak tersertifikasi halal menjadi celah dan ruang untuk beredarnya produk-produk makanan, obat-obatan dan kosmetika yang tidak halal ke pasaran (masyarakat).

Kata Kunci: Sertifikasi halal, LPPOM-MUI, makanan halal, dan ulama.

\section{A. Pendahuluan}

Makanan sebagai kebutuhan primer manusia menjadi hal yang diatur oleh hampir semua ajaran agama. Aturan terhadap makaanan dalam setiap agama sangat variatif. Cara memperoleh, nilai gizi, manfaatnya bagi tubuh manusia; makanan yang boleh atau tidak boleh dikonsumsi; waktu makan yang dianjurkan dan tidak dianjurkan merupakan beberapa contoh yang diatur.

Islam mengajaran tentang makanan yang halal dan thoyibah. Halal dalam ajaran Islam menyangkut dua hal, yakni dzat yang terkandung dalam makanan dan proses memperolehnya harus sesuai dengan syariat Islam. Menurut Yusuf Qardhawi, kriteria konsumsi pada makanan halal adalah berhemat, tidak bermewah-mewahan, menjauhi hutang, menjauhi kebakhilan dan kekikiran. Pernyataan Yusuf al-Qardhawi tersebut didasarkan pada firman Allah SWT dalam Al-Qur'an surat al-Baqarah: 168. Ayat ini menjadi dasar kewajiban yang mutlak bagi setiap muslim untuk mengkonsumsi makanan yang halal lagi baik (thayyib) dan tidak bersikap buruk (Qardhawi; 1997, 137).

Dalam perkembangannya, ajaran Islam tentang makanan halal melahirkan mekanisasi yang dikenal dengan sertifikasi halal. Kajian tentang sertifikasi halal makanan telah berkembang pesat, dalam skala global maupun lokal di Indonesia. Menariknya, sertifikasi halal bukan saja menjadi milik atau dilaksanakan di negaranegara yang mayoritas muslim, tetapi juga di negara-negara yang minoritas muslim. Sertifikasi halal yang berbasis normativitas Islam ternyata dapat diterima oleh negaranegara yang minoritas muslim, mengapa bisa demikian? Ini tidak lepas berkesesuaiannya dengan hidup kemodernan dan kesehatan. Bahkan produk makanan halal telah dijadikan branding di banyak negara.

Di Indonesia, dengan kuantitas penduduk muslim sekitar $85 \%$, menjadi pendorong lahirnya Undang-Undang No. 33 Tahun 2014 Tentang Jaminan Produk Halal. Pasal 2 undang-undang ini manyatakan bahwa "Penyelenggaraan jaminan produk halal berasaskan; pada asas pelindungan, asas keadilan, asas kepastian hukum, asas akuntabilitas dan transparansi, asas efektivitas dan efisiensi, serta asas profesionalitas". Begitupula pada pasal 3 yang menyatakan "Penyelenggaraan jaminan produk halal bertujuan memberikan kenyamanan, keamanan, keselamatan, dan kepastian 
ketersediaan produk halal bagi masyarakat dalam mengonsumsi dan menggunakan produk, serta bertujauan untuk meningkatkan nilai tambah bagi pelaku usaha untuk memproduksi dan menjual produk halal". Selain itu, terdapat pula Fatwa MUI No. 518 Tahun 2001 tentang pedoman dan tata cara pemeriksaan dan penetapan pangan halal, pasal 1 hurup (b) menyatakan "Pemeriksaan pangan halal adalah pemeriksaan tentang keadaan dan tambahan dan bahan penolong serta proses produksi, personalia dan peralatan produksi, sistem menajemen halal, dan hal-hal lain yang berhubungan langsung maupun tidak langsung dengan kegiatan produksi pangan halal" dan juga Fatwa MUI No. 519 Tahun 2001 tentang lembaga pelaksana pemeriksaan pangan halal, pasal 2 menyatakan "Pelaksanaan kegiatan pemeriksaan pangan sebagaimana dimaksud dalam Pasal l, meliputi: pemeriksaan dan atau verifikasi data pemohon, pemeriksaan proses produksi, pemeriksaan laboratorium, pemeriksaan pengepakan, pengemasan dan pemyimpanan produk, pemeriksaan sistem transportasi, distribusi, pemasaran dan penyajian, pemrosesan dan penetapan Sertifikasi Halal".

Penelitian-penelitian terdahulu belum banyak mengungkap bagaimana normatifitas Islam yang diformalkan dalam hukum positif negara berupa Undang-Undang dan fatwa halal MUI dipraktekkan ke dalam standarisasi, mekanisasi, proses dan pengawasan sertifikasi halal produk makanan. Oleh karena itu, penelitian ini bertujuan menjelaskan hukum positif negara berupa undang-undang dan fatwa MUI tentang makanan halal dipraktekkan ke dalam standarisasi, mekanisasi dan proses sertifikasi halal produk makanan melalui kajian secara mikroskopis pada Lembaga Pengkajian Pangan Obat-Obatan dan Kosmetika-Majelis Ulama Indonesia (LPPOM-MUI) Sulawesi Tenggara.
Peneliti juga mendiskusikan mekanisasi sertifikasi halal produk makanan di LPPOM-MUI Sulawesi Tenggara dalam memberi perlindungan terhadap konsumen muslim.

\section{B. Makanan Halaldan Kesucian}

Makanan halal, dalam ajaran Islam, erat hubungannya dengan menjaga kesucian. Menjaga kesucian makanan yang diasupkan ke dalam tubuh. Makanan menjadi sumber nutrisi yang diproses menjadi darah yang mengalir ke seluruh tubuh. Konsep ini dikenal dengan istilah tazkiyah sebagaimana diungkapkan oleh $\mathrm{M}$. Arifin Hamid. Konsep ini bukan saja menjadi semacam "pedoman" dalam dalam makanan, tetapi dalam skala yang luas dalam hal manusia mempersiapkan dan melaksanakan kegiatan-bisnis yang karenanya manusia memperoleh penghasilan yang digunakan sebagai nafkah dalam keluarga yang dibelanjakan untuk makanan. Teori tazkiyah berorientasi mempersiapkan bisnis sesuai syariah, juga dapat difungsikan sebagai standar evaluasi untuk semua jenis kegiatan di bidang ekonomi untuk dinyatakan sebagai bisnis yang sesuai dengan syariah (Hamid; 2013).

Kata tazkiyah berasal dari suku kata zakka, yuzakki, tazkiyah memiliki arti antara lain tumbuh, suci, dan berkah (Karzon; 2010, xv). Dalam konteks makna mensucikan seperti ayat Al-Quran, Qad aflaha man tazakka (sungguh sangat beruntung bagi yang selalu mensucikan diri, Surat As-Syams: 9-10). Watuzakkiehim (dan untuk membersihkan diri mereka, Surat At-Taubah : 103). Balillah yuzakki man yasya'(namun Allah hanya mensucikan kepada siapa yang dikehendaki-Nya, Surat An-Nisa': 49), dan seterusnya.

Perintah Al-Quran untuk mensucikan semua amal-amal termasuk dalam konteks pengelolaan harta agar senantiasa dalam koridor tazkiyah tidak terbantahkan lagi. Baik yang berasal dari Al-Quran maupun Assunnah. Konsep 
tazkiah (kesucian) meliputi makna bersih dan sah secara lahiriyah dan suci secara batiniah. Karena itu, makanan dan sebuah usaha senantiasa diharuskan mencakupi kedua dimensi tazkiyah tersebut. Tazkiyah (kesucian) dibangun berdasarkan ayat AlQuran antara lain, ya ayyha annas kulu mimma fil ardhi halalan tayyiban (wahai manusia makanlah apa yang ada di bumi halal yang baik, QS. Al-Baqarah: 168), la ta'kulu amwalakun bainakum bil bhatili (janganlah memakan harta di antara kamu dengan jalan bathil, QS. An-Nisa: 29), wa ahallallahul bai'a waharra ariba (dan halal jual beli dan haram riba, QS. A-Baqarah: 275). Hadis nabi wa an malihi min aena iktasabahu wa fi ma wadha'ahu (dan mengenai hartamu dari mana kamu memperolehnya dan bagaimana pula kamu menggunakannnya); Kullu lahmin nabata min haramin pannaru aula bihi, (setiap daging yang tumbuh dari sesuatu yang haram tiada lain balasannya adalah api neraka, (Hamid, 2013).

Konsep kesucian, dengan dasar sejumlah ayat dan hadis tersebut, juga didukung beberapa hal mendasar, sebagai berikut: pertama, dalam konsep fikih dikenal lima kategori hukum atau alahkamul khamzah yang lazim juga disebut sebagai hukum taklify, yaitu pembebanan hukum terhadap perbuatan manusia dan terhadap objek/benda. Kedua, masih dalam konsep fikih kehamaran sesuatu itu (tindakan atau objek) disebabkan karena dua hal, yaitu (1) karena zatnya (al-haramu lizatihi), objeknya yang memang diharamkan antara lain daging babi, khamar, narkoba, prostitusi, bangkai, darah, hewan tertentu, usaha judi, prostitusi, riba, dan lainnya. (2) haram selain zatnya (al-haramu lighairi zatihi), yaitu berkaitan dengan proses dan cara memperolehnya, antara lain riba, gharar, zhalim, sumpah palsu, penipuan, persaingan tidak sehat, tidak jujur, penimbunan (iktinaz), dan segala tindakan tidak amanah lainnya (Hamid; 2013).

\section{Tangan Ulama Bernama LPPOM- MUI}

Ajaran Islam tentang makanan halal untuk menjaga kesucian tubuh, di Indonesia mengalami pelembagaan. Pada awalnya, norma halal dipraktekan secara perorangan, terutama oleh tokoh-tokoh muslim dan komunitas masyarakat muslim yang taat, berupa kesadaran secara selektif dalam mengkonsumsi makanan yang sesuai dengan syariat Islam. Organisasi-organisasi keislaman menjadi bagian yang penting dalam menyuarakan untuk dijaminnya makanan yang halal oleh negara. Suara organisasi-organisasi Islam yang mewakili umat Islam yang besar terlembagakan menjadi Majelis Ulama Indonesia (MUI). Untuk memberi jaminan makanan halal kepada masyarakat muslim, MUI membentuk Lembaga Pengkajian Pangan, Obat-obatan, dan Kosmetika (LPPOM-MUI) pada tanggal 6 Januari 1989.

Beberapa literatur menyebutkan bahwa latar belakang berdirinya lembaga ini bermula dari kasus lemak babi dalam bahan-bahan makanan. Kasus tersebut merupakan temuan penelitian Dr. Tri Susanto dari Universitas Brawijaya Malang. Kasus ini kemudian menjadi isu nasional yang berdampak pada perekonomian nasional. Kasus ini menyentuh sensitifitas keberagamaan orang Islam yang menghendaki adanya jaminan setiap produk yang beredar di pasaran memenuhi kriteria halal. Menyadari tanggung jawabnya untuk melindungi masyarakat muslim, Majelis Ulama Indonesia mendirikan Lembaga Pengkajian Pangan, Obat-obatan, dan Kosmetika yang disingkat LPPOM MUI. Lembaga ini didirikan sebagai bagian dari upaya memberikan ketentraman batin umat Islam, terutama dalam 
mengkonsumsi pangan, obata-obatan, dan kosmetika (Aditya; 2011, 3).

Pada awal-awal tahun berdirinya, lembaga ini banyak mengadakan seminarseminar, diskusi-diskusi dengan para pakar baik ilmu syariah maupun ilmu kesehatan dan pangan, dan kunjungankunjungan studi banding serta muzakarah. Tahap ini merupakan tahap penyusunan konsep dan standar kehalalan dan prosedur pemeriksaan sesuai dengan perkembangan ilmu pengetahuan dan teknologi dengan kaidah agama. Selama kurang lebih lima tahun, LPPOM-MUI mempersiapkan berbagai konsep, standar dan instrumen sertifikasi halal dan membangun kerjasama dengan lembagalembaga terkait.

Sertifikat halal pertama yang dikeluarkan oleh LPPOM MUI di awal tahun 1994 untuk konsumen maupun produsen. Dalam pelaksanaan proses sertifikasi, LPPOM MUI bekerjasama dengan Badan Pengawas Obat dan Makanan (BPOM), Kementerian Agama, Perguruan Tinggi, dan Kementerian Koperasi dan UMKM. Khusus dengan Badan Pengawas Obat dan Makanan (BPOM) dan Kementerian Agama, sertifikat halal MUI merupakan persyaratan dalam penentuan label halal dalam kemasan (Aditya; 2011, 3).

Dalam catatan sejarah, kepemimpinan LPPOM-MUI pernah dipimpin oleh beberapa tokoh, periode pertama dipimpin oleh Dr. M. Amin Aziz yang memimpin LPPOM-MUI sejak tahun 1989 hingga 1993. Periode kedua adalah kepengurusan di bawah pimpinan Prof. Dr. Aisyah Girindra, yang memimpin dari tahun 1993 hingga tahun 2006. Periode kepengurusan tahun 2006 hingga tahun 2011 Dipegang oleh HM. Nadratuzaman Hosen, namun pada Oktober 2009 terjadi pergantian kepengurusan, yakni dengan adanya pengurus antar waktu (PAW). Dalam kepengurusan tersebut, Ir. Lukman Hakim M.Si. dipercaya sebagai pimpinan
LPPOM-MUI hingga tahun 2010. Pada bulan September 2010, LPPOM-MUI kembali melakukan pergantian kepengurusan dan mempercayakan Ir. Lukman Hakim M.Si. hingga sekarang (Aditya; 2011, 3).

Untuk membangkitkan kesadaran masyarakat dalam mengkonsumsi produk halal, LPPOM-MUI merancang program sosialisasi dan informasi publik antara lain melalui seminar, workshop, kunjunag ke produsen halal, penerbitan majalah, pengelolaan media informasi online serta penyelenggaraan pameran produk halal Indonesia Halal Expo (INDHEX) yang digelar secara setiap pertahun. Selain itu, demi meningkatkan pelayanan pelanggan, LPPOM-MUI membangun Management Informasi System (MIS), yang memudahkan masyarakat, khususnya para pelaku usaha yang hendak mengajukan sertifikasi halal bisa melakukan secara online melalui situs www.halalmui.org. Berbagai langkah dan kebijakan LPPOMMUI di bidang sertifikasi halal yang dimaksudkan untuk terus meningkatkan pelayanan kepada masyarakat dalam memperoleh produk halal.

Di wilayah Sulawesi Tenggara, LPPOM-MUI berdiri setelah LPPOMMUI Pusat berusia 23 tahun, tepatnya di tahun 2007 yang diprakarsai oleh Ketua MUI Provinsi Sulawesi Tenggara, KH. Chadidi, BA. melalui rapat dengan institusi/lembaga terkait, yakni Kepala bidang Urusan Agama Islam (Drs. Muchdar Bintang), mewakili Kakanwil Agama Provinsi Sultra, Ka Balai POM Provinsi Sultra (Dra. Husnah Thaha, Apt) dan mantan Kapala Balai POM Provinsi Sultra (Dra. Hj. Wa Ode Asnah Ganiu, Apt). Dalam rapat ini, MUI Provinsi Sultra belum mendapat respon dan belum disetujui oleh Kanwil Departemen Agama atas alasan yang berwenang menerbitkan Sertifikat Halal adalah Kanwil Agama Provinsi Sultra bukan MUI. Tahun 2008 Kanwil Departemen Agama mulai 
menerbitkan Sertifikat Halal tanpa melalui proses audit dan dengan biaya yang sangat rendah berkisar antara Rp. 150.000-Rp. 400.000 dan bahkan ada yang gratis. Ada 130 Sertifikat Halal yang telah diterbitkan dan berlaku untuk jangka waktu 5 tahun (Dokumen LPPOM-MUI Sultra).

Tahun 2010 MUI Sultra mendapatkan kunjungan dari LPPOM MUI Pusat dan LPPOM MUI Sulawesi Selatan dan setelah kunjungan tersebut, MUI Provinsi Sultra mengadakan rapat untuk pendirian LPPOM MUI Provinsi Sultra sekaligus menetapkan Direktur yang memenuhi persyaratan. Kemudian, Dewan Pimpinan MUI Provinsi Sultra menerbitkan Surat Keputusan No.Kep024/MUI-Sultra/VII/2010, Tanggal 12 Sya'ban 1431 H/23 Juli 2010 M, tentang Struktur Pengurus LPPOM-MUI Provinsi Sultra Priode 2010-2015.

Pada awalnya lembaga yang dibentuk hanya terdiri dari 5 orang pengurus dan tanpa ada fasilitas kantor maupun petunjuk teknis. Struktur pengurus LPPOM-MUI Provinsi Sultra periode 2010-2015 adalah Direktur: Dra Hj. Wa Ode Asnah Ganiu, Apt. Sekretaris: Drs. H. Mashuri, M.Pd. Bendahara: Dra. Yuni Susilowati. Bidang Auditing: Drs. Saiful Azmi. Bidang Sosialisasi dan Kerjasama: Drs. H. Lanawe.

Setelah melalui konsultasi dan kepesertaannya dalam Rakernas LPPOM MUI di Jakarta, penyempurnaan kepengurusan LPPOM MUI Provinsi Sulawesi Tenggara dilakukan dan diresmikan oleh Gubernur Sulawesi Tenggara, H. Nur Alam, SE, di Hotel Ataya Kendari pada tanggal 4 Mei 2012, sesuai Surat keputusan Dewan Pimpinan Majelis Ulama Indonesia Provinsi Sulawesi Tenggara Nomor: Kep-0ll/MUISultra/III/2012 tanggal 8 Rabiul Tsani 1433 H/2 Maret 2012 M tentang susunan Pengurus LPPOM-MUI Provinsi Sultra Periode 2012-2017. Berdasarkan Surat Keputusan Majelis Ulama Indonesia Provinsi Sulawesi Tenggara tersebut,
Dewan Pelaksana Lembaga Pengkajian Pangan, Obat-obatan dan Kosmetika Majelis Ulama Indonesia mengukuhkannya dengan Surat Keputusan No: SK 08/Dir/LPPOM MUI/III/12 tanggal 29 Maret 2012 tentang Pengukuhan Susunan Kepengurusan Lembaga Pengkajian Pangan, Obat-obatan dan Kosmetika Majelis Ulama Indonesia Sulawesi Tenggara masa Khidmat 20122017.

Struktur pengurus LPPOM MUI Provinsi Sultra periode 2012-2017 adalah sebagai berikut: Direktur:Dra Hj. Wa Ode Asnah Ganiu, Apt.Wakil Direktur: Prof. Dr. I. Sahidin, M.Si.Kepala Bidang Sekretariat:Drs. H. Adami dan Suriatin, S.Sos., M.Si.Bendahara:La Mane Angga, SE. Kepala Bidang Auditing:Titi Andriani Tasman, SH. dan Drh. Rosmala.Kepala Bidang Sistem:H. Iwan Sahibo, SE. Jaminan Halal: Drs. Saiful AzmiBidang Informasi Halal:H. Hasanuri, SH., M.HI., Drs. H. La Nawe. Bidang Sosialisasi: Drs. H. Mashuri, M.Pd. Promosi Halal: Drh. Sangia Muljabar.

Sejak tahun 2013 LPPOM MUI bersekretariat di Islamic Centre Jl. $\mathrm{H}$. Abdullah Silondae No. 81 Kendari satu gedung dengan MUI Provinsi Sultra. Namun seiring kebijakan gubernur Nur Alam yang mengalihfungsikan tempat Islamic Centre untuk Bank Sultra, maka gedung Islamic Centre diganti dengan pembangunan Gedung Bank Sultra yang hingga kini belum selesai pembangunannya. Sementara LPPOMMUI terkatung-katung tidak diberi fasilitas kantor, atas inisiatif direktur LPPOM-MUI, Dra Hj. Wa Ode Asnah Ganiu, Apt., sekretariatnya dibawa numpang di rumahnyadi Jl. Flamboyan No. 4 Kota Kendari. Di tahun 2018, LPPOMMUI Sultra berkantor gedung MUI, Jl. Budi Utomo Kompleks P2ID Kendari.

Mandat yang diamanatkan kepada LPPOM-MUI adalah: (1) Melaksanakan program MUI untuk memeriksa kehalalan makanan, obat-obatan, dan kosmetika 
yang beredar, baik produk domestik maupun produk impor; (2) Mengajukan hasil pemeriksaan dan pengkajian secara terperinci kepada komisi fatwa MUI sebagai bahan pertimbanganuntuk menentukan status hukum kehalalan produk; (3) Mengadakan berbagai kegiatan untuk menjalin kerjasama dengan instansi-instansi pemerintah dan swasta, baik dalam negeri maupun luar negeri; (4) Membentu LPPOM MUI daerah bersama dewan pimpinan MUI.

Kesadaran arus besar umat Islam tentang makanan halal dan tumbuhnya bisnis yang berbasis syariah di Indonesia mendorong lahirnya sebuah undangundang yang memnajamin tersedianya produk halal bagi konsumen muslim di Indonesia menjadi sebuah keharusan agar implementasi Sertifikat Halal semakin diperkuat oleh payung hukum yang jelas.

Pada tahun 2014 DPR RI mengesahkan Undang-Undang No. 33 tentang Jaminan Produk Halal. Undangundang ini dipandang sebagai jawaban sebagai payung hukum atas banyaknya tuntutan kebutuhan seiring dengan perkembangan teknologi dan tuntutan masyarakat yang semakin tinggi tentang produk halal, agar masyarakat Indonesia terhindar dari bahaya produk-produk yang mengandung zat berbahaya dan terhindar dari oknum yang ingin meraup untug sebanyak banyaknya tanpa mengeluarkan biaya besar.

\section{Dari Norma Agama ke Techno- Standar Sertifikasi Halal}

Dari norma, kaidah fikih Islam, dan juga Undang-Undang 332014 tentang makanan halal dioperasionalisasikan ke dalam standar, prosedur dan kriteria jaminan produk halal. Ketika penilitian ini dilaksanakan, Undang-undang 332014 masih dalam proses sosialisasi. Lembaga Badan Penyelenggara Jaminan Produk Halal (BPJPH), sebagaimana diamanatkan dalam Undang-undang tersebut sedang dalam proses pembentukan sehingga LPPOM-MUI masih melaksanakan fungsinya melaksanakan sertifikasi halal.

Standar produk halal adalah produk yang memenuhi syarat kehalalan sesuai syariat Islam, yakni: pertama, tidak mengandung babi dan bahan yang berasal dari babi. Kedua, semua makanan dan minuman yang tidak mengandung khomer. Ketiga, tidak mengandung bahanbahan yang diharamkan seperti darah, kotoran, bangkai, dan bahan-bahan yang berasal dari organ manusia. Keempat, semua bahan yang berasal dari hewan halal yang disembelih menurut tata cara syariat Islam. Kelima, semua tempat penyimpanan, tempat penjualan, pengolahan dan transportasinya tidak boleh digunakan untuk babi, jika pernah digunakan untuk babi dan barang-barang tidak halal lainya harus terlebih dahulu dibersihkan dengan tata cara yang diatur dalam syariat Islam.

Dalam sistem yang dibuat LPPOM MUI, standar halal tersebut, dibuat kriteria keharusan bagi perusahaan terkait bahan, produk, fasilitas produksi, prosedur tertulis untuk aktivitas kritis, dan kemampuan telusur (dokumen LPOMMUI): pertama, bahan. Perusahaan harus membuat daftar bahan (mencantumkan semua bahan baku, bahan tambahan dan bahan penolong) yang digunakan untuk menghasilkan produk yang disertifikasi. Dalam borang sertifikasi produk makanan halal, ketentuan daftar bahan sebagai berikut: (1) Daftar bahan dibuat sesuai dengan format; (2) Daftar bahan harus dibuat rangkap dua dan bermatrai, ditandatangani oleh ketua tim manajemen halal, pimpinan perusahaan dan dikirimkan ke LPPOM MUI untuk ditandatangani oleh LPPOM MUI; (3) Daftar bahan yang telah disetujui oleh LPPOM MUI didistribusikan kebagian yang terkait proses produksi halal, seperti bagian seleksi bahan, pembelian, pemeriksaan dan penyimpanan bahan dan produksi; (4) Perbaikan daftar bahan 
harus dilakukan bila terjadi perubahan daftar bahan karna adanya perubahan bahan, produsen bahan atau dokumen pendukung bahan,. Revisi daftar bahan tidak perlu dimintakan tandatangan ke LPPOM MUI setiap ada perubahan, tetapi cukup dimintakan tanda tangan setiap enam bulan sekali. Dalam daftar bahan yang diperbaiki, bahan baru diberi tanda dan dilampirkan dokumen persetujuannya.

Kedua, produk. Perusahaan harus membuat daftar produk dan matriks bahan vs produk untuk semua produk yang disertifikasi halal. Perusahan harus membuat diagram alair proses produksi untuk produk yang disertifikasi halal. Ketiga, fasilitas produksi. Semua fasilitas produksi yang digunakan untuk menghasilkan produk, baik milik perusahaan sendiri maupun yang disewa dari pihak lain harus didaftarkan dan menjadi ruang lingkup implementasi Sistem Jaminan Halal. Fasilitas ini mencakup semua fasilitas yang digunakan dalam proses produksi sejak dari penyiapan bahan, proses utama hingga ke penyimpanan produk perusahaan harus meminta persetujuan dari LPPOM MUI setiap penambahan fasilitas produk baru untuk produk yang sudah disertifikasi.

Keempat, Prosedur Tertulis untuk Aktivitas Kritis. Dalam rangka menjaga kehalalan produk secara konsisten, kami menerapkan aturan/prosedur sebagi berikut: (1) Dalam pembuatan produk baru, tim manajemen halal akan memilih bahan yang telah ada pada daftar bahan yang telah disetujui oleh LPPOM MUI; (2) Jika harus menggunakan bahan di luar daftar bahan tersebut (bahan baru/bahan lama dengan produsen baru), maka tim manajemen halal akan meminta persetujuan tertulis dari LPPOM sebelum menggunakan bahan tersebut;

Melaksanaan pembelian bahan yang sesuai dengan daftar bahan yang telah disetujui oleh LPPOM: (a) Pembelian bahan baru/bahan lama dengan produsen baru dilaksanakan setelah ada bukti tertulis persetujuan LPPOM MUI; (b) Mencatat semua transaksi pembelian dan penyimpanan bukti-bukti pembelian lengkap dengan merk serta kodenya; (c) Setiap bahan datang sebelum digunakan produksi diperiksa kesesuaian antara informasi pada label kemasan bahan dengan informasi yang tercantum dalam dokumen pendukung bahan. Informasi yang diperiksa mencakup nama bahan, nama produsen, negara produsen dan adanya logo halal bila dipersyaratkan; (d) Menjalankan kegiatan produksi sesuai dengan daftar bahan yang telah disetujui oleh LPPOM MUI; (e) Melakukan proses produksi yang bersih dan bebas dari bahan haram dan najis; (f) Meminta persetujuan tertulis dari LPPOM MUI setiap penambahan fasilitas produksi; (g) Melakukan penyimpanan bahan dan produk yang dapat menjamin bebas dari kontaminasi dari segala sesuatu yang haram dan najis; (h) Memastikan produk halal perusahaan terdistribusi dengan baik yaitu tidak terkontaminasi silang dengan produk lain yang diragukan kehalalannya; (j) Mendaftarkan produk baru dengan merk yang sama untuk disertifikasi hala sebelim dijual dipasaran.

Kelima, Kemampuan Telusur (Traceability). Dalam rangka pelaksanaan proses produksi halal dan mengoptimalkan pelaksanaan $\mathrm{SJH}$ diperusahaan, maka kami membuat sistem administrasi pembukuan dan dokumentasi yang rapi, sehingga akan mempermudah penelusuran kembali jika terjadi permasalahan dalam pelaksanaan produksi halal. Administrasi pembukuan yang terutama adalah pencatatan pembelian bahan baku, bahan tambahan dan bahan penolong pada buku catatan pembelian bahan.

Kriteria thoyibah dalam sebuah produk makanan berdasarkan penjelasan direktur LPPOM MUI adalah; (1) bersih, (2) tempat produksi telah menyediakan 
dan mengatur penempatan bahan, pencampuran, pengolahan pada masingmasing tempat yang khusus, (3) posisi kamar mandi/WC tidak berhadapan dengan ruang produksi, (4) Tidak ada rambut dan kotoran yang jatuh/masuk dalam bahan produksi atau tempat produksi. (5) Alat produksinya bersih. (6) Pengerjaannya menggunakan sarung tangan atau pakaian kerja standar. (7) Tidak ada jejak kaki binatang, sarang labalaba, cicak atau kotoran binatang dalam ruang tempat produksi. Inilah unsur higienisitas yang dalam bahasa agama disebut thoyibah.

\section{E. Kluster dan Proses Sertifikasi Halal di LPPOM MUI Sultra}

1. Kluster Produk yang Disertifikasi Halal LPPOM MUI Sultra

LPPOM MUI mensertifikasi beragam jenis produk, klaster produk berdasarkan list produk yang telah tersertifikasi sejak tahun 2013-2017 adalah sebagai berikut: (1) Daging dan produk daging olahan, (2) Ikan dan produk ikan olahan, (3) Minuman dan bahan minuman, (4) Roti dan kue, (5) Tumbuhan dan produk tumbuhan olahan, (6) Makanan ringan, (7) Ikan dan produk ikan olahan, (8) Minuman dan bahan minuman, (9) Rumah potong hewan, (10) Restauran dan katering dan (11) Tepung, pati dan produk turunan.

Sebenarnya, menurut keterangan direktur LPPOM MUI, klaster produk yang disertifikasi oleh LPPOM MUI lebih dari itu. Hanya saja, yang telah ada produknya yang terdaftar dan tersertifikasi di LPPOM MUI Sulawesi Tenggara baru seperti yang tertulis di atas. Harapannya, ketika kesadaran halal dalam masyarakat dan pengusaha telah tumbuh, akan lebih banyak lagi dan bahkan semua produk makanan, obat-obatan dan kosmetika yang beredar kepada masyarakat semuanya tersertifikasi. Dilihat dari kelompok usahanya, pengusul sertifikasi halal dapat dikelompokan ke dalam klaster: (1) Usaha Mikro Kecil dan Menengah (UMKM), (2) Usaha Kecil Menengah (UKM) (3) UD, CV dan PT.

Berdasarkan data yang terdapat di LPPOM MUI Sulawesi tenggara, sejak tahun 2013 sampai tahun 2018 telah mengeluarkan sertifikat sebanyak 120 dari 100 perusahaan dan 1.198 jenis produk (data LPPOM-MUI Sultra).

\section{Pendaftaran Nama dan Jenis Produk yang Disertifikasi}

LPPOM MUI Sultra menerima pendaftaran dari pelaku usaha dalam pengurusan sertifikasi halal dengan ketentuan para pelaku usaha mengisi borang baik secara individu ataupun dibantu oleh petugas LP-POM MUI. Setelah borang selesai terisi, kemudian borang tersebut dikembalikan ke LP-POM MUI. Kemudian LP-POM MUI memverifikasi borang tersebut, apakah sudah lengkap atau belum, jika belum lengkap, maka LP-POM MUI meminta pelaku usaha untuk melengkapi kembali.Jika borang tersebut selesai terisi secara lengkap maka LP-POM MUI akan melakukan pembahasan tentang biaya akad. Terkait biaya akad LP-POM MUI membedakan antara pelaku usaha kecil/mikro, menengah, dan perusahaan besar yang berbadan hukum.

Biaya akad ditentukan berdasar beberapa kriteria di antaranya adalah perusahaan yang mengajukan sertifikasi di dalam atau di luar kota Kendari dan kategori perusahaannya UMKM, UD, atau CV, PT. Biaya akad untuk UMKM dalam kota Kendari adalah Rp. 3.000.000,- dan UMKM di luar Kota Kendari Rp. 3.500.000,- untuk pengajuan sertifikat halal yang diajukan oleh UD biaya akadnya adalah Rp. 4.000.000,- CV. Rp. 5.000.000,dan PT. Rp. 6.000.000,-. Apabila akad pembayaran sudah disepakati, maka pelaku usaha melakukan transver biaya ke rekening LP-POM MUI.

Apabila pelaku usaha telah akad dan menginformasikan kesiapannya didaudit, 
LPPOM MUI akan mengundang dan meminta 2 orang dari perusahaan untuk mengikuti platihan SJH (Sistem Jaminan Halal). Platihan sitem jaminan halal (SJH) ini sangat penting, pemiliki usaha atau orang yang ditugaskan oleh perusahaan untuk mengikuti pelatihan $\mathrm{SJH}$ harus muslim. Orang yang dilatih ini, akan diposisikan dalam perusahaannya sebagai ketua auditor halal internal(KHI) untuk menjaga kualitas kehalalan sebuah produk secara berkelanjutan.

Pelatihan SJH merupakan bentuk transformasi pengetahuan dan sistem halal untuk diterapkan oleh sitap pelaku usaha, mereka harus betul-betul yakin bahwa bahan baku yang mereka gunakan harus sesui dengan ketentuan syariah Islam (halal).Ketentuan halal tersebut mengcakup; (1) SDM. (2) Bahan baku. (3) Prosedur. (4) Sampai kepada produk tersebut jadi dan siap untuk dipasarkan. (5) pengangkutan (Tarnsportasi /mobilisasi) produk tersebut pun harus dalam keadaan halal tidak boleh di campur dengan kendaraan bekas mengangkut barang haram.

\section{Auditor: Menjadi Saksi dan Wakil Ulama}

Dalam panduan umum sistem jaminan halal yang dikeluarkan MUI, auditor didefinisikan sebagai orang yang diangkat oleh LPPOM MUI setelah melalui proses seleksi kompetensi, kualitas dan integritasnya dan ditugaskan untuk melaksanakan audit halal. Auditor LPPOM MUI berperan sebagai wakil ulama dan saksi untuk melihat dan menemukan fakta kegiatan produksi halal di perusahaan.

Kualifikasi sebagai auditor LPPOM MUI adalah: (1) Berlatarbelakang pendidikan bidang pangan, kesehatan, obat-obatan, dan kosmetika. (2) Lulus tes dan memiliki sertifikat sebagai Auditor yang diselenggarakan oleh MUI pusat. (3) Memiliki wawasan keagamaan Islam yang baik dan berintegritas. (4) Memiliki kepedulian terhadap perlindungan konsumen muslim, kehalalan dan kesehatan.

Mekanisme rekrutment: (1) MUI pusat menginformasikan akan rekrutmen Auditor, (2) calon auditor mendaftar dengan melengkapi berkas, (3) Pembekalam materi dari MUI tentang sertifikasi Halal (4) Free test, (5) Tes, (6) Penentuan yang lulus sebagai auditor, (7) penerbitan sertifikat auditor, Pembekalan teknis, atitud dan integritas, (9) Ujicoba sebagai auditor mendapingi auditor senior (lama) minimal 3 kali audit. Jumlah Auditor yang dimiliki LPPOMMUI Sultra sebanyak 34 orang, dengan rincian 18 auditor Kabupaten/Kota dan 16 auditor Provinsi.

\section{Visitasi dan Audit Lapangan}

Periode audit di LPPOM-MUI Sultra disesuaikan dengan usulan yang masuk dari para pelaku usaha. Adakalanya dalam satu bulan tidak ada yang mengajukan, sehingga tidak ada audit. Jika pelaku usaha mengajukan sertifikasi halal, yang bertugas mengaudit dan memvisitasi perusahaan dan produk yang diajukan adalah auditor. Tugas dan fungsi auditorLP-POM MUI adalah saksi dan wakil ulama. Dalam visitasi lapangandan proses audit, tugas auditor (1) mengecek kebenaran semua standar halal yang tertulis dalam borang yang diajukan pengusaha/perusahaan, (2) membuat berita acara laporan hasil audit.

Standar pelaksanaan audit lapangan adalah: (1) Direktur LPPOM MUI mengeluarkan surat tugas kepada 2 orang auditor untuk melaksankan audit hlal. (2) Auditor yang ditugaskan dijemput oleh pelaku usaha ke perusahaan yang akan diaudit. (3) Opening audit di perusahaan/tempat usaha produk akan disertifikasi.

Selanjutnya, auditor melaksanakan audit sesuai borang yang diajukan oleh pelaku usaha terhadap semua unsur standar dan 
kriteria halal sesuai yang telah ditetapkan oleh LPPOM MUI. Setelah auditor selesai melaksanakan tugasnya mengaudit lapangan terhadap suatu produk, biasanya dilaksanakan selama satu hari penuh, maka auditor membuat laporan audit. Audit diakhiri dengan closing auditatau penutupan audit lapangan. Dalam closing auditini, auditor menyampaikan saran dan masukan perbaikan jika masih ditemukan unsur, faktor, dan atau proses yang belum sepenuhnya sesuai dengan kriteria atau standar halal LPPOM MUI. Selanjutnya, pelaku usaha berkewajiban mengantarkan auditor LPPOM MUI kembali ke tempat semula.

\section{Rapat Auditor}

Rapat auditor merupakan forum yang diadakan setelah dilaksanakannya audit lapangan. Rapat auditor tidak hanya dihadiri oleh auditor yang bertugas melaksanakan audit lapangan terhadap suatu produk perusahaan, tetapi dihadiri oleh semua auditor. Semua auditor LPPOM MUI ikut berperan membahas laporan hasil audit terhadap suatu produk. Hal utama yang yang dibahas adalah laporan hasil audit lapangan. Data inilah yang dijadikan bahan untuk rapat auditor.

Waktu pelaksanaan rapat auditor ditentukan oleh direktur LPPOM MUI setelah adanya laporan hasil audit lapangan terhadap suatu produk. Rapat auditor dipimpin langsung oleh direktur LPPOM MUI, selanjutnya auditor yang melaksanakan tugas mengaudit lapangan suatu produk melaporkan hasil-hasil auditnya dengan tampilan power point sehingga dapat diketahui ditail-detail data riil lapangan yang meliputi: (a) Keadaan perusahaan; (b) Bahan baku yang digunakan; (c) Zat tambahan; (d) Proses pembuatan; (e)

Alat produksi;

Pengemasan/pengepakan;

Penempatan; (h) Distribusi.

audit $\begin{array}{cr}\text { Setelah auditor } & \text { pelaksana } \\ \text { lapangan } & \text { selesai }\end{array}$ mempresentasikan laporannya, maka semua auditor yang hadir diminta untuk membahasnya. Di sinilah terjadi diskusi yang serius terkait kelayakan sebuah produk memenuhi standar halal atau tidak. Kesimpulan dari rapat auditor ini, jika disimpulkan sebuah produk memenuhi kriteria standar halal, maka hasilnya akan dibawa ke rapat komisi fatwa MUI. Jika sebuah produk disimpulkan belum memenuhi kriteria standar halal, maka tidak dapat diajukan ke komisi fatwa dan direktur LPPOM MUI akan menerbitkan surat kepada pelaku usaha pengusul bahwa pruduknya belum dapat diberikan sertifikat halal dan LPPOM melakukan pembinaan agar pelaku usaha tersebut mengajukan kembali proses sertifikasi halal ke LPPOM MUI.

\section{Sidang Komisi Fatwa}

Sidang komisi fatwa merupakan sidang puncak yang otoritatif dari otoritas ulama. Di sinilah peran dan kedaulatan ulama sebagai pemiliki otoritas pemberi fata berfungsi.Peserta sidang komisi fatwa adalah ketua dan angggota Komisi Fatwa MUI, direktur LPPOM MUI dan para auditor.

Pelaksanaan sidang komisi fatwa ditentukan berdasarkan adanya hasil rapat auditor. Data yang telah disimpulkan memenuhi standar halal dalam rapat auditor dipresentasikan oleh auditor dalam forum sidang komisi fatwa. Sidang komisi fatwa dibuka oleh direktur LPPOM MUI dan dipimpin oleh ketua komisi fatwa MUI. Agenda pembahasan dalam 
forum ini adalah: (a) Laporan auditor dari hasil audit lapangan dan rapat auditor; (b) Diskusi pembahasan ulamakomisi fatwa dan auditor; (c) Jawaban auditor, dan menunjukkan sampel produk yang akan disertifikasi; (d) Penentuan kelayakan sertifikasi halal terhadap produk yang diajukan; (e) Kesimpulan dan penutup. Jika dalam kesimpulan rapat komisi fatwa sebuah produk memenuhi standar halal, maka dikeluarkanlah fatwa halal terhadap produk tersebut dan diberi sertifikat halal.

\section{Pemberian Sertifikat Halal}

Sertifikat produk halal diberikan oleh MUI kepada perusahan pengusul yang di dalamnya tercantum: (a) Logo halal MUI; (b) Nama perusahaan; (c) Alamat perusahaan; (d) Jenis produk; (e) Nomor sertifikat; (f) Status: baru/perpanjangan.

Masa berlaku sertifikat halal MUI adalah selama 2 tahun. Pelaku usaha harus mengurus kembali jika masa berlakunya telah habis. Sertifikat diserahkan oleh direktur LPPOM MUI kepada pelaku usaha biasanya secara kolektif. Karena dalam forum penyerahan sertifikat, direktor LPPOM MUI menyampaikan himbauan-himbauan tentang produk halal kepada pelaku usah.

\section{Pengendalian dan Kontroling \\ Sertifikat Halal}

Setelah sebuah produk tersertifikasi halal, LPPOM MUI melaksanakan pengendalian atau Controling terhadap sertifikat yang telah dikeluarkan. Bentuk pengendaliannya adalah: (a) Laporan dari perusahaan ke LPPOM MUI per 6 bulan; (b) Pembinaan secara berkala, pembinaan tersebut bisa dengan lisan atau pun tulisan dalam bentuk surat peringatan; (c) Memperhatikan laporan dan informasi masyarakat; (d) Inspeksi mendadak
(Sidak). Alasan adanya sidak berdasarkan informasi direktur LPPOM MUI bermula dari kecurigaan dan pelaporan masyarakat maka di lakukanlah sidak tesebut; (e) Apabila langkah-langkah pembinaan tersebut masih belum dipatuhi maka langkah yang terakhir adalah pencabutan sertifikat halal. (sampai saat ini belum pernah ada kasus pencabutan sertifikat halal).

\section{F. Perlindungan Konsumen Melalui Sertifikasi Halal}

Sertifikasi halal yang dijalankan oleh LPPOM-MUI, selain menjalankan ajaran Islam, dilihat dari sudut pandang konsumen merupakan upaya perlindungan konsumen (muslim). LPPOM-MUI berperan sebagai lembaga dan aktor yang menjaga setiap produk makanan, minuman, obat-obatan, dan kosmetika yang akan beredar di pasaran. Namun peneliti melihat, belum semua pelaku usaha memiliki kesadaran dan kemauan mensertifikasikan semua produk-produk yang mereka produksi dan perdagangkan ke pasaran. Dalam pandangan mereka (pelaku usaha), jika telah memiliki izin BP-POM sudah cukup. Alasan mereka pada aspek biaya sertifikasi yang mahal dan proses audit lapangan dipandang akan membuka dan diketahui kondisi sesungguhnya keadaan "dapur" perusahaan mereka. Belum efektifnya pemberlakuan Undang-undang 33 tahun 2014 tentang Jaminan Produk Halal, menyebabkan tidak semua produk makanan diwajibkan untuk disertifikasi halal. Artinya, masyarakat belum terlindungi; Pemberlakuan untuk semua produk makanan disertifikasi halal menjadi sebuah keniscayaan.

Kendala mendasar yang dihadapi dalam proses-proses sertifikasi halal produk makanan dapat diidentifikasi: pertama, masih rendahnya kesadarankepedulian masyarakat terhadap produk halal. Kedua, keengganan para pengusaha 
untuk mendaftarkan

dan mensertifikasikan produk industrinya pada sertifikasi halal. Ketiga, kurangnya dukungan dari para pihak terutama pemerintah dan lembaga-lembaga ekonomi. Keempat, tarik ulur kelembagaan antara di bawah MUI dan Kementerian Agama.

Di sisi lain, pada saat pemberlakuan sertifikasi halal terhadap produk makanan, obat-obatan dan kosmetika, dalam waktu bersamaan tidak diterapkan sertifikasi haram terhadap produk yang tidak tersertifikasi. Dengan demikian, celah dan ruang untuk beredarnya produk-produk makanan, obat-obatan dan kosmetika yang tidak halal masih terbuka sangat lebar.

\section{G. Kesimpulan}

Dari pembahasan data hasil penelitian dapat disimpulkan sebagai berikut: pertama, standar halal ditetapkan oleh LPPOM MUI mengacu pada ajaran syariah Islam dan standar teknis. Standar halal berdasarkan syariah adalah: (1) tidak mengandung babi dan bahan yang berasal dari babi. (2) semua makanan dan minuman yang tidak mengandung khomer. (3) tidak mengandung bahan-bahan yang diharamkan seperti darah, kotoran, bangkai, dan bahan-bahan yang berasal dari organ manusia. (4) semua bahan yang berasal dari hewan halal yang disembelih menurut tata cara syariat Islam. (5) semua tempat penyimpanan, tempat penjualan, pengolahan dan transportasinya tidak boleh digunakan untuk babi, jika pernah digunakan untuk babi dan barang-barang tidak halal lainya harus terlebih dahulu dibersihkan dengan tata cara yang diatur dalam syariat Islam. Standar teknis penentuan halal yang tercantum dalam borang sertifikasi halal LPPOM MUI adalah (1) bahan, (2) produk, (3) fasilitas produksi, (4) prosedur tertulis untuk aktivitas kritis, dan (5) kemampuan telusur. $\begin{array}{rc}\text { Kedua, } & \text { sertifikasi halal yang } \\ \text { ditugaskan } & \text { kepada }\end{array}$ berperan melindungi konsumen (muslim) melalui standarisasi dan techno saintifikasi sertifikasi halal terhadap produk-produk makanan, minuman, obatobatan dan kosmetika yang akan bereadar kepada masyarakat. Secara tidak langsung, yang dilakukan LPPOM MUI adalah sedang melindungi konsumen dengan cara tidak sembarang memberi label halal tanpa melalui proses sertifikasi halal.

\section{DAFTAR PUSTAKA}

Afroniyati, Lies. 2014. "Analisis Ekonomi Politik Sertifikasi Halal" dalam Jurnal Kebijakan da Administrasi Publik JKAP vol 18 No 1-Mei.

Aminuddin, Muh. Zumar. 2016. "Sertifikasi Produk Halal: Studi Perbandingan Indonesia dan Thailand" dalam Jurnal Shahih Vol. I, No. 1, Januari-Juni.

Al-Qardhawi, Yusuf.1997. Norma dan Etika Ekonomi Islam, terjemahan Zainal Arifin Jakarta: Gema Insani Press.

Asep Syarifuddin Hidayat dan Mustolih Siradj. 2015. "Sertifikasi Halal Dan Sertifikasi Non Halal Pada Produk Pangan Industri" dalam Jurnal Ahkam Vol. XV, No. 2, Juli.

Bahruddin, Muh. 2010. "Peroblem Sertifikasi Produk Halal Produk Pangan Hewani" dalam Jurnal Asas Vol. II, No. 1, Januari.

Bungin, Burhan. 2008. Penelitian Kualitatif, Jakarta: Kencana Prenada Media Group.

Friska Ester dan I Ketut Sandi Sudarsana. 2015. "Peranan Sertifikasi Halal Bagi 
Konsumen Dalam Aspek Perlindungan Konsumen" dalam Jurnal Kertha Semaya Vol. 03, No. 02, Januari.

Fischer, Johan. 2011. The Halal: Frontier Muslim Consumers In A Globalized Market, Palgrave Macmillan.

Hamid, M. Arifin. 2013. "Ekonomi Syariah Wajib Hukumnya" Makalah Seminar Internasional Antar Bangsa Sejarahdan Budaya di Alam Melayu 26-27 Nopember 2013.

Hasan, KN. Sopyan. 2014. "Kepastian Hukum Sertifikasi Dan Labelisasi Halal Produk Lapangan" dalam Jurnal Dinamika Hukum Vol. 14 No. 2 Mei.

Ibrahim, Jabal Tarik. 1996. "Standardisasi, Sertifikasi, dan Labelisasi Halal Serta Pengawsannya” dalan Jurnal Bestari.

Idri.2015.Hadis Ekonomi: Ekonomi dalam Persfektif Hadis Nabi, Jakarta: Prenadamedia Group.

Imam Salehudin dan Basuki Muhammad Mukhlish. 2012. "Pemasaran Halal: Konsep, Implikasi Dan Temuan Di Lapangan" Papers. Ssrn.com.

J. Moloeng, Lexy.1998. Metodologi Penelitian Kualiatif, Bandung: Remaja Rosdakarya.

Karzon, Anas Ahmad. 2010. Tazkiyatun Nasf. Akbar Media: Jakarta

Langko, M. Amir. 2014. "Kewenangan Komisi Fatwa Mui Dalam Penyelesaian Sertifikasi Halal LP.POM MUI" Jurnal Al-Bayyinah Vol 1, No. 1.

Mian N. Riaz dan Muhammad M. Chaudry. 2003. Halal Food Production, London: CSR Pers.
Muhajir, Noeng.1989. Metodologi Penelitian Kualitatif, Yogyakarta: Rake Surasin.

Putra, M. Ade Septiawan. 2015. Kewenagan LP-POM MUI dalam Penentuan Sertifikasi Halal Pasca Berlakunya UU No. 33 Tahun 2014, UIN Syarif Hidayatullah Jakarta.

Ramlan dan Nahrowi. 2014. "Sertifikasi Halal Sebagai Penerapan Etika Bisnis Islami Dalam Upaya Perlindungan Bagi Konsumen Muslim" dalam Jurnal Ahkam Vol. XIV, No. 1, Januari.

Rosyidi, Suherman. 1996.Pengantar Teori Ekonomi: Pendekatan Kepada Teori Ekonomi Mikro dan Makro, Jakarta: Raja Grafindo Persada.

Soejono dkk. 1999.Metode Penelitian Suatu Pemikiran dan Penerapannya, Jakarta: Reneka Cipta.

Sugiono. 2001. Metode Penelitian Bisnis, Bandung: Alfabeta.

Sukandarrumidi. 2002. Metodologi Penelitian, Yogyakarta: Gadjah Mada University Press.

Surachman,Winarno. 1990. Pengantar Penelitian Ilmiah, Bandung: Tarsita.

Supriyatni, Rinny. 2011. "Eksistensi dan Tanggung Jawab Majlis Ulama Indonesia dalam Penerapan Sertifikasi dan labelisasi Halal Produk Pangan di Indonesia" Jurnal Al-Iqtishad Vol. III No. 2 Juli.

Utami, Pujiati. 2011. "Sertifikasi Halal Sebagai Upaya Peningkatan Kualitas Produk Olahan Komoditas Pertanian Unggulan Daerah" dalam Jurnal Agritech Vol. XIII, No. 1, Juli. 
UU No. 8 Tahun 1999 Tentang Perlindungan Konsumen.

UU No. 33 Tahun 2014 Tentang Jaminan Produk Halal.

Fatwa MUI No.518 Tahun 2001 Tentang Pedoman dan Tata Cara Pemeriksaan dan Penetapan Pangan Halal.
Fatwa MUI No.519 Tahun 2001 Tentang Lembaga Pelaksana Pemeriksaan Pangan Halal

www.m.republika.co.id, diakses pada tanggal 25 November 2017.

www.rri.co.id, diakses pada tanggal 25 November 2017. 